\title{
PHRASEOLOGICAL UNITS RELATED TO PARTS OF BODY PRESENTED IN KARAKALPAK EXPLANATORY DICTIONARY
}

\author{
Mambetmuratova M. T. \\ $(\mathrm{PhD})$ Doctoral Student, \\ Nukus, NSPI named after Azhiniyaz, \\ Nukus. Republic of Karakalpakstan, \\ Uzbekistan
}

Article DOI: https://doi.org/10.36713/epra6689

DOI No: 10.36713/epra6689

\begin{abstract}
The article informs that the phraseological units related to body parts (somatisms) presented in the explanatory dictionary of the Karakalpak language on the basis of phraseological materials. It is justified the body parts such as back, mouth, leg, head, finger, waist, hand, foot, face in the dictionary.
\end{abstract}

KEY WORDS: register, phraseology, word, dictionary, lexical group, bodyparts.

\section{INTRODUCTION}

In the history of science and culture of each nation, the formation of an explanatory dictionary is a great event in comparison with other dictionaries, because only such kind of dictionaries have an opportunity to demonstrate the nation's history, its achievements in science and culture for several centuries.

The richness of the vocabulary plays an important role in the development of any language. Dictionaries play a special role in teaching the rich vocabulary of our language to the younger generation and the general public. Vocabulary is a very simple, concise scientific task to use, and its correctness in all respects is great importance for the reader. Dictionaries, despite their simplicity and conciseness, contain a lot of information in their work. The materials collected to convey this information, the high level of its scientific discussions testify to the value of the dictionary.

One of the major works of the Karakalpak language lexicon is the Explanatory Dictionary of the Karakalpak language. This dictionary explains the meaning of words used in the Karakalpak language, including the meanings of phraseologies. In explanatory dictionary, the transmission of phraseology is carried out by a symbolic sign - a rhombus $(\diamond)$. Once the meanings of the word register are given in full, the phraseology with the word is written after the rhombic sign and its meanings are explained, examples are given.

Karakalpak Explanatory dictionary also provides rich phraseological materials, most of which consists of phraseological units (somatisms) related to body parts.

\section{RESULT AND DISCUSSIONS}

The dictionary uses the following phrases related to body parts: back, mouth, legs, head, tongue, eyes, fingers, liver, nails, heart, wrists, hips, buttocks, waist, arms, feet, abdomen, chin, shoulders, pelvis, face, height, occiput, armpit. Many of them are used in the creation of several phrases: Arqa súyew - support, helper, trustworthy person. Arqa súyer jalǵı taw1 q1z apası Aysultan edi. (Kh. Seyitov). (The only person to support was her sister Aisultan).

Arqası qozıw - excitement, curiosity. Sóylese arqası qozǵan, Júyrik bolıp kimnen ozǵan. (Ótesh shayır). (When he spoke, his back was moved, and he was ahead of all). Den sawliqtıń arqasi - the reason for good health is to be healthy without pain, to have a healthy body. Den sawlıqtın 
arqasında júzge shıǵıwıńız ushın, ózlerimizdi kútiwimiz kerek. (K. Smamutov). (We need to take care of ourselves so that you can reach the hundred due to health) [1.98]. The given phraseologies differ from each other not only in their meaning, but also in the function of the keyword in the phrase. In the first and second phraseologies, the main word is from the verb, but the phraseology of arqa which means back does not mean the meaning of the action. In the third phraseology, although the pronoun is derived from the noun, the noun is used in accordance with the suffix when it loses its meaning. Its similarity can be found in other vocabularies. Compare: There is a birthmark on my son's back. (in the full meaning). Thanks to my parents, I have reached this level (in the auxiliary meaning). A wוz salıw - a) mouthwash, perforating. Qoy qoraǵa awız salıp boldım (M.Daribaev). (I put the mouth on the sheepfold) b) biting, trying, snatching. Joldan nedewir jer qashıqlaǵan waqıtta tanaday bir haywan kese belden shıǵa kelip, zángilikke awız saldı (K. Sultanov). (Some distance from the road, an animal came out and put its mouth on the bell). Aw1z tiyiw - tasting of a piece of food, bread, which is ready to be eaten. Tandir japqan jengeylerden bar mirat, Ruxsat joq awı tiymey ótiwge (I. Yusupov). There is an offer from sisters-in-law who are baking bread, there is no permission to leave without touching the mouth [1.122].

Both of these phraseologies were used in connection with the action, but in the first, the change of metaphorical meaning had a stabilizing character. Therefore, in the first phraseology, the main word is considered to be verbal. However, in the second sense of this phraseology, the main word is considered to be a verb.

In the Karakalpak language there are a lot of phraseologies, the main word of which is given by the word salıw which has various meanings as give a hand, say a word, have a look, breathe, etc. In the second phraseology, the pronoun is a verb and has a hyperbolic meaning, in which it is stated that eating in such a small amount is equivalent to touching only the mouth.

Ayaq alis - the state of affairs, the direction of the case, the mood, the appearance, the situation, someone's actions, behavior. Apa endi tınısh bol, kelini-q1zdıń ayaq alısı jaqsı kórinedi (K. Irmanov). (Calm down now, the bride's behaviour looks good). Ayaq astı -any place, unknown place, unnecessary things. Álle qaydan ushıp kep, Basıldı ayaq astına (T. Seitzhanov). (Where did it appeared? It was trampled underfoot). Ayaq suwitıw - Cooling of the feet, breathing, resting on the feet. ... Eger ara-tura ayaq suwita qoysa, shomdı astına qoyıp otırıwǵa kerek, q1ysayıp jata qoysa jambasına tósek etip salıwǵa kerek (Abdraimov). (... If the legs are cold from time to time, they should be placed under the pillow, and if they are crooked, they should be placed on the hips). Ayaq ushina qoyılıw - put on the tip of the foot, the tip of the foot, the surface of the foot. Eger qız táwir bolsa, bas ushındaǵı shıra ayaq ushına qoyılsin (K. Aimbetov). (If the girl feels well, remove the candle from the tip of the head to the tip of the foot [1.134].In almost all of these phraseologies, the keyword is the root word, and in the phraseology of foot cooling, the keyword is the verb. The word underfoot, when combined with the auxiliary verbs to do, creates a phraseology that means humiliation, contempt.

Qoy kózli bala - a child with sheep's eyes, eyes like sheep's eye, blue eyes. Atamurattıń sonǵ1 sózine jawrınlıdan kelgen qoy kózli bala taǵ 1 da qarsılast1 (T.Kaipbergenov). (Atamurat's last words were again opposed by a sheep-eyed boy) In our opinion, in this phraseological unit sheep-eyed is a definite word with a stabilizing character, and the word child is used as an appositive, instead of the word child can be put a word that means someone: sheep-eyed boy, sheep-eyed girl, sheep-eyed bride, etc. Therefore, this phraseology had to be placed under another register word. Bes barmaq - [1. 277] - five fingers. Berdibay kúle shiray menen qasına kelip, bes barmaǵın jazıp qol kóterip sálem berdi. (Berdibay came to him with a smile and greeted him with five fingers). Suq barmaq - the index finger, the longest finger in the middle of the five fingers. Barmaq tislew - regret, resentment, repentance for past. The following two examples are used in our language as phraseology. But the first is considered as common word. If this word sequence was given in the form of bes barmaq birdey emes (five fingers are not equal), it could be fully characterized as a phraseology. In addition, there are two idioms related to the word finger: torsiyısqan barmaqtay - like a thumb, like a wet, round finger, bes barmaǵınday biliw - to know like five fingers, to know everything, to know the details.

We can take the second of the given phraseologies as a whole phraseological unit.

The word bas (head) is one of the most widely used words in the Karakalpak language. In addition to its phraseological combinations, it has 13 meanings, and the number of phraseologies is 77 . We have decided to divide them into groups according to grammatical differences. Most of the phraseologies that contain the main word are used in the sense of nouns and verbs. Phrasal verbs used in the sense of a noun: alone, head, thumb, headgear, skull, head scarf, head-legs, head grief, head cause, head duty, head grief, head of the enemy, head of the hearth, head of the case, head tied, headline, headmaster.

Phrasal verbs used in the sense of the verb: to bow one's head, to experience, to meet, to leave, to fall, to raise one's head, to refuse, to come to one's head, to bow one's head, to release one's head, to 
wrap one's head, to cover one's head, to sew one's head to raise one's head, to shake one's head, not to give up.

The methods of formation of the abovementioned phraseologies are diverse. In the phraseology that comes in the sense of a noun, there are phraseologies that have the most important, prestigious meaning: the main flag, the main wrestler, the main article, the main race, and so on. In our opinion, the head scarf listed in this line cannot be a phraseology, because the scarf itself is a square that attracts others, it has no other meaning. If this word is replaced by the word handkerchief, it can be taken as a phraseology.

In the Karakalpak language, the word bel (back) is productively involved in the formation of phraseology. There are 12 phraseologies in the explanatory dictionary in which it participates: Bel bala [1.261] - a) a child born from himself; b) the son of the truth, the son of the country, who cares about the country and the people. Bel baylaw, bel buwıw - to want something, to start something, to take a risk, to start, to stand alone. Belge túyiw, belge túsiw - marking of all sorrows, worries, burdens and so on. . Beli búgiliw, beli buratılıw waist flexion, grief, anxiety. Beli mertiliw -disability caused by the weight of work, lifting a heavy object. Bel bermew - perseverance, endurance to strength and hardship. Most of these idioms are used in relation to action.

The word bet (face) is also used productively in the creation of phraseologies. In addition to its main and variable meanings, explanatory dictionary also has 30 phraseological meanings. Due to their large number, we have chosen to focus on their meanings only where necessary, and to mention the rest: face to face, pressing on the face, throwing at the face, looking at the face, soot on the face, seeing the face in the mirror. Some of them are different versions of the same phraseological unit while others are not relevant to the criteria of phraseology. For example, the concept of the phraseology of bet súrtiw is given as wiping face. ... The girl wiped her face with a handkerchief and looked at me. One of the main features of phraseology is that the word sequence has a variable, figurative second meaning. Wiping the face does not have any variable meaning, its components can be easily replaced: wiping the face, wiping the head, wiping the hands, etc. Therefore, such phrases should not be included in the list of phraseologies.

Phraseologisms in the presence of the word bilek (wrist) are formed by the stabilization of epithets and are used in the sense of appearance. Aq bilek - beautiful wrist Jińishke bilek, názik bilek -thin, delicate and weak wrist. Talmas bilek strong and powerful wrist. Som bilek, jumırı bilek
- muscular and strong wrist. Arıstay bilek - long and big.

The word eye is used very effectively in phraseology. The dictionary contains 120 phraseologies composed in its presence. They act in essence: eye contact, whitening, yellowing of the eyes, insatiability, staring, inversion, blinking, [2.298] etc. The dictionary defines the term gegirdek (trachea) as follows:

"Trachea- a tube-like portion of the respiratory tract that connects the larynx with the bronchial parts of the lungs. Q1zıl gegirdek bolıw -having a big argument. Óz gegirdegin oylaw- to think of one's own circle, to think of one's own goal. Gegirdekke uriw - to eat, to spend on one's own. Gegirdekke suw búrkiw - shouting, talking up." [2.15]

Initially the word is described as a part of the body. Then it is shown that it is as a part of the phraseology.

There are a lot of phraseologies in the Karakalpak language that come with the names of body parts. The phraseological units quzl gegirdek bolıw, óz gegirdegin oylaw, gegirdekke urıw, gegirdekke suw búrkiw play an important role. They are used in literary works on various stylistic purposes. For example: 1. Tilewmuratov balalardıń qasına kelse, zavod direktorı Dawjanov penen Tilemis qızıl kegirdek bolıp atır eken. (K.S.) (When Tilevmuratov came to the fishermen, the director of the plant Dauzhanov and Tilemis were arguing.) 2. Iyun ayınıń on birinshi aqshamında "Jaqsiliqtıń" keńsesindegi gegirdekke suw búrkispe kúta háwijine minip attı (Sh.S.). (In the evening of the eleventh of June the shout in the office of "Djaksilik" was increasing.) 3. Xojaniyazov kempir menen ǵarriniń qızıl kegirdek bolıp aytısa ketkenin sezip, artına jalt qaradi (KS). (Khozhaniyazov glanced behind him, feeling that the granny and grandad began arguing). The phraseology of q1zıl gegirdek bolıw in the dictionary, which means a strong argument, is used as kegirdek in the example of the work of Sh. Seyitov. The dictionary does not specify the variant of the term kegirdek. In everyday speech it is pronounced in the form of kegirdek, and this variant is also common. It is also used in the language of the work with the meanings of loud screams and fights. In the works of Sh. Seyitov it is sometimes used in the form of kegirdek, sometimes in the form of gegirdek. The phraseological unit of gegirdekke suw búrkiw which is also very close in meaning to the phraseology of q1zil kegirdek bolıw. If the dictionary gives the meaning of shouting, rising up, it preserves the meanings and means quarreling, shouting. The meanings of shouting and arguing with each other are also given in the phraseology of the language of K. Sultanov's works. 
In the dictionary the verb form of the word gegirdek is formed by adding the suffix of -le and the suffix -tey to form adjective.

Gegirdeklesiw (v) - Shouting, arguing

Gegirdektey (adj)- looks like a trachea. Thus, the term of this body part is explained in the dictionary by its meanings as a part of phraseology, as a verb and as an adjective.

In explanatory dictionary the word qol (hand) is given as part of 17 phraseologies. Qattı qollı miser. Qol qawsiriw- bowing, kneeling. Jekke qollı -not to be a helper, on one's own. Qollı bold1 - it was lost. Qol-ayaqta turmaw [3.166] - being anxious, screaming.

The word taban (foot) is one of the most effective words used in the construction of phraseologies. The dictionary contains 15 idioms related to it, most of which are verb idioms: Taban jıltıratıw - to go fast. Tabanın qirıp alıw - not make others close to you, not let them pass. . Tabanı tayıw - a guilty dismissal from the workplace. Tabanlap júriw- [4.254]- being stubborn.

\section{CONCLUSIONS}

In the explanatory dictionary of the Karakalpak language, terms of body parts occupy wide place. Their meanings are explained in detail. The dictionary gives huge opportunity to understand the meanings of the terms of body parts, use them productively in literary works and appropriately in speech.

Thus, phraseologies related to body parts are common in the Karakalpak language. They make up the majority of lexical groups of phraseologies. Among them there are a great number of phraseological units whose meanings related to the action.

In summary, the study of exploring phraseological units in Karakalpak Explanatory Dictionary allows the user to have a correct understanding of the phraseological units and accurately determine their meaning.

\section{REFERENCES}

1. Explanatory dictionary of the Karakalpak language. Vol I. N., 1982. p. 402

2. Explanatory dictionary of the Karakalpak language. Vol II. N., 1984. p. 388

3. Explanatory dictionary of the Karakalpak language. Vol III N., 1988. p.368

4. Explanatory dictionary of the Karakalpak language. Vol IV. N., 1992. p 633 